\title{
أسلوب النكرار في القرآن الكريم
}

\section{Muhammad Luthfil Anshori}

Sekolah Tinggi Agama Islam Al-Anwar Sarang Rembang

mluthfil.anshori@yahoo.com

DOI: http://dx.doi.org/10.18326/lisania.v1i1.56-73

\begin{abstract}
This study discusses analytically the phenomenon of repetition (al-takrâr) contained in the Qur'an. It aims to conceptually describe the phenomenon of repetition in the Qur'an, including: the definitions, types, and functions. The results of this study reveal the disagreements among scholars and academics related to this phenomenon. Some argue that the phenomenon of repetition in the Qur'an is one side of deficiency, or even disgrace that can damage the beauty and majesty of the Qur'an. Yet others argue that it is one common language style used in Arabic literature, which has specific aims and functions. In fact, the repetition gives a deep impact and impression to its readers.
\end{abstract}

Keywords: Uslûb, Repetition, Qur`an

\begin{abstract}
Abstrak
Penelitian ini mengkaji secara eksploratif dan analitis tentang fenomena pengulangan (al-takrâr) yang terdapat di dalam al-Qur`an. Tujuan dari penelitian ini adalah untuk mendeskripsikan secara konseptual tentang adanya fenomena pengulangan di dalam al-Qur`an, meliputi; definisi, jenis, serta fungsi dari pengulangan tersebut. Hasil dari penelitian ini mengungkapkan adanya perselisihan pendapat di kalangan ulama dan akademisi terkait fenomena ini. Sebagian kalangan berpendapat bahwa, adanya fenomena pengulangan di dalam al-Qur'an merupakan salah satu sisi kekurangan, bahkan aib, yang bisa merusak keindahan dan keagungan alQur`an itu sendiri. Namun sebagian yang lain justru menyatakan bahwa fenomena pengulangan merupakan salah satu gaya bahasa yang lazim digunakan dalam sastra Arab, yang memiliki tujuan serta fungsi tertentu. Bahkan, adanya pengulangan tersebut memberikan pengaruh dan kesan yang mendalam bagi para pembacanya.
\end{abstract}

Kata Kunci: Uslûb, Pengulangan, al-Qur’an 


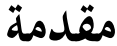

القرآن هو كتاب الله عز وجل الذى يتضمن كلماته إلى خاتم رسله وأنبيائه محمد عليه الصلاة والسّلام. وللقرآن خصائص كثيرة، منها الإعجاز . ووجوه الإعجاز في القرآن متنوعة وعديدة، فكل شيئ منه لا نظير له، فهو باهر في ألفاظه وأسلوبه، في تأليفه

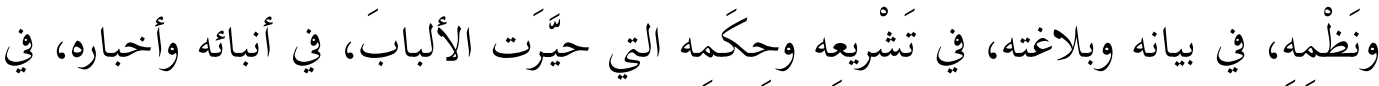
تاريخِه وحفظه، وفي عُلومه التى لا تنقطع ولا تَقِف عندَ غاية. وانطلاقا مما سبق، بذل العلماء والدارسون جهودهم في كل كل عصر ودمص لفهرم

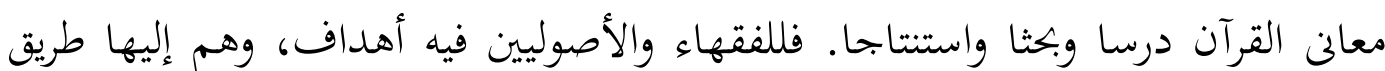

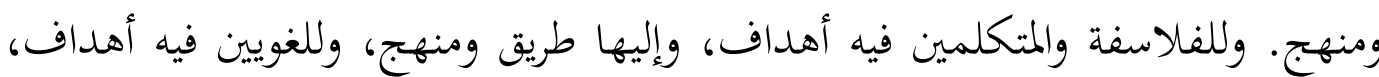
ولهم إليها شرعة ووسيلة. ولغير هؤلاء من طلاب العلم والدرس أهداف ومناهج. وفي هذا البحث، يريد الباحث درس القرآن الكريم من ناحية خصائصه التعبيرية،

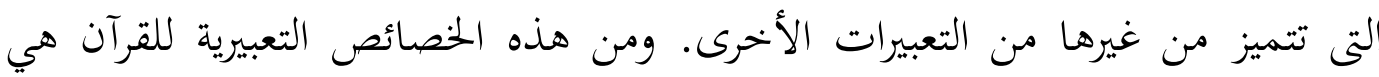

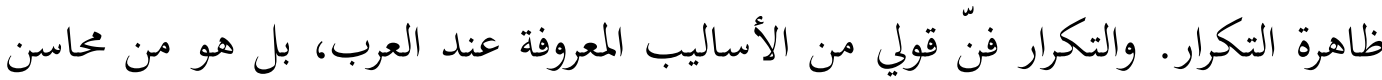

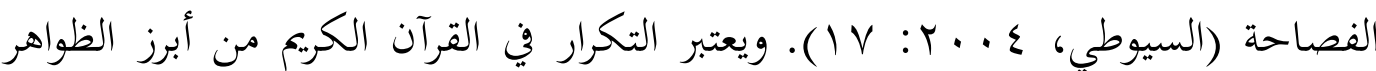
البلاغية التي شغلت الباحثين قديما وحديثا، واشتغالهم هذا يدل على الأهمية التي تحملها هذه الظاهرة في طياتما، فعلى الرغم من كونها كثيرة في لغة العرب. وهي من فنون القول

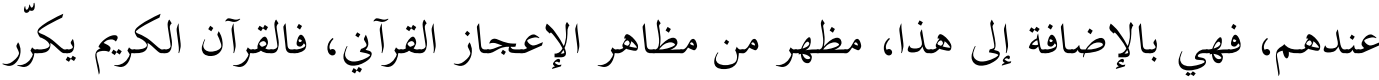

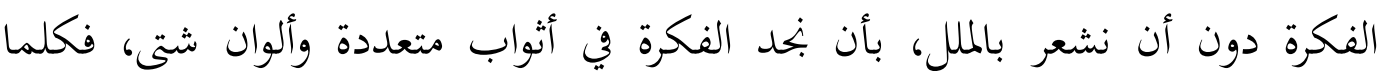
ظهرت في لون ازدادت قرارا في النفس والفكر، فإذا هي قد وصلت إلى القلب والعقل في

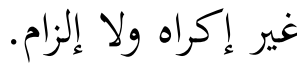

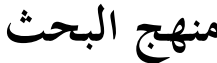

سيتبع الباحثث في هذه الدراسة المنهج الاستقرائي التحليلي الموضوعي، وذلك من خلال النقاط التالية: (1) جمع الآيات القرآنية التي توجد فيها أساليب التكرار،

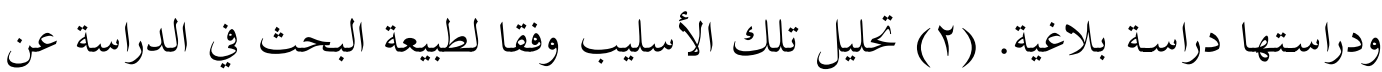
الأسرار البلاغية. (ّ) الاستدلال بأقوال العلماء والمفسرين مع التوثيق في الحاشية 
حسب الأصول، مع الاستعانة بمصادر ومراجع عامة مما له علاقة بالبحث. (ع) كتابة الآيات القرآنية المذكورة بالرسم العثماني وعزوها إلى سورها مع ذكر رقم الآية، وتوثيق ذلك في متن البحث تجنبا لإثقال الحواشي. (0) الوقوف على اللطائف والإشارات

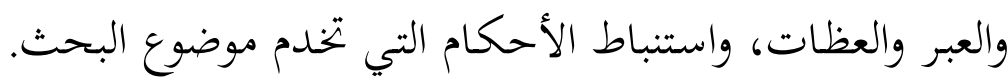
مفهوم التكرار

جاء في لسان العرب التكرار في اللّغة أصله من الكرّ بمعنى الرّجوع، ويأتي بمعنى

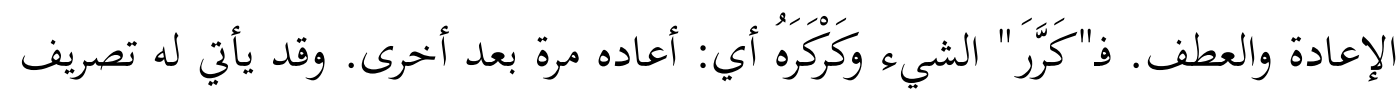

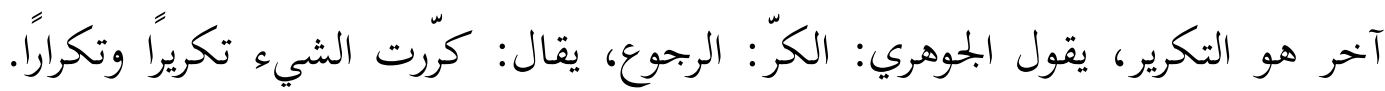

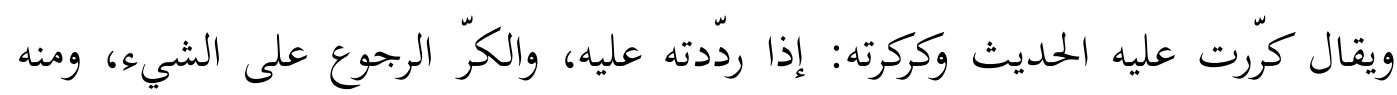
التُكرار والتكرّة بمعنى التّكرار.

وجاء في صحاح الجوهريّ، كرّت الشيء تكريرا وتكرارا. قال أبو سعيد الضّرير:

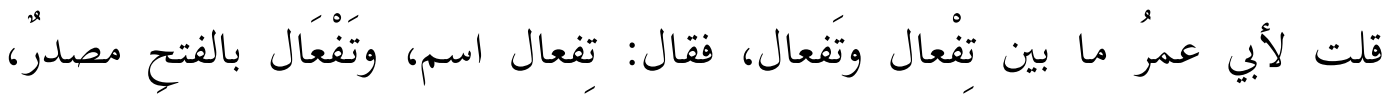

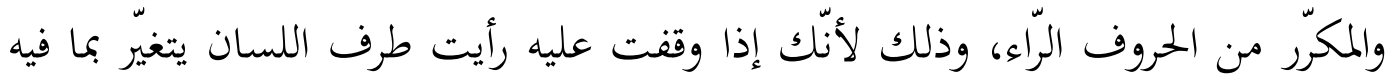

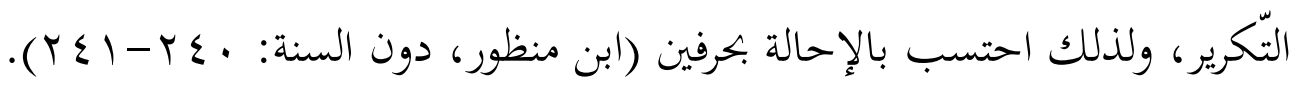

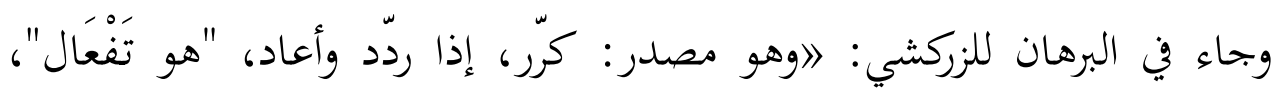

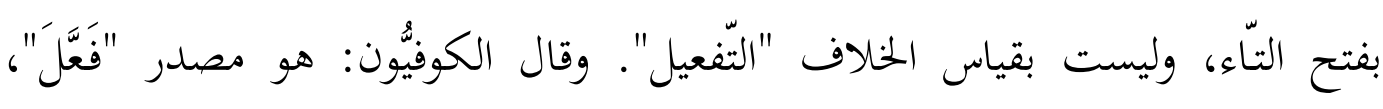

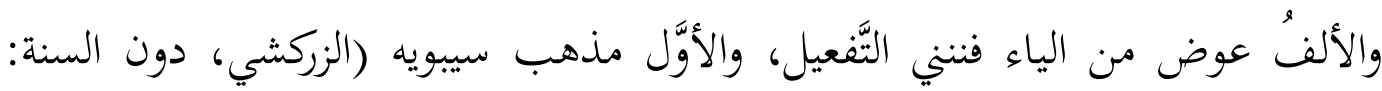
$\cdot(\wedge$

ومن معانيه أيضا: البعث وبتحيد الخَّقُ بعد الفناء، وكأنّني به يريد أن يقول

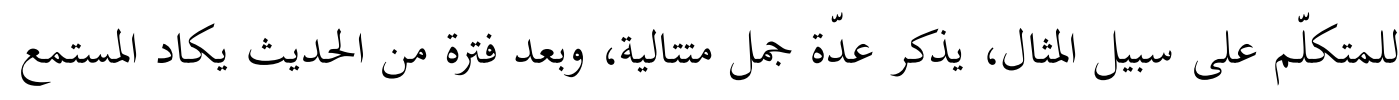

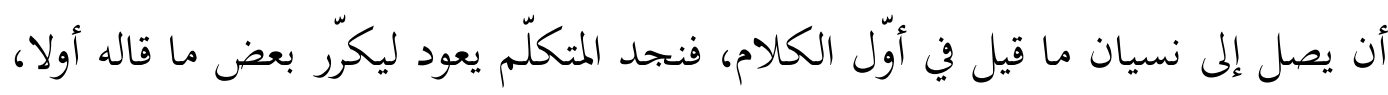

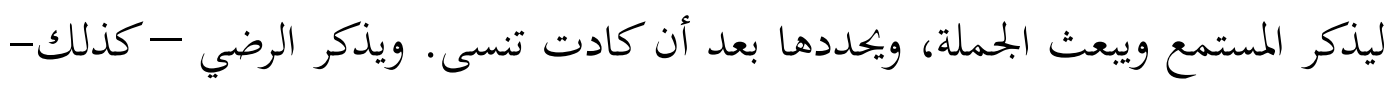

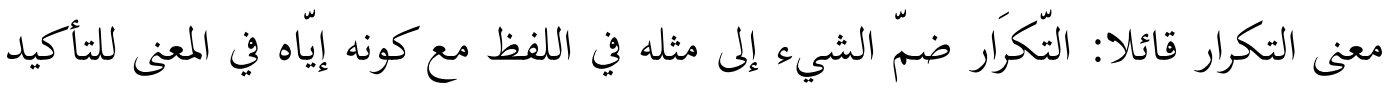

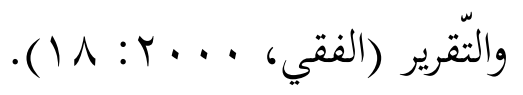


ويقول ابن فارس في معحم مقاييس اللغة، "الكافُ والرّاء أصلّ صحيح يدلُ على كلى

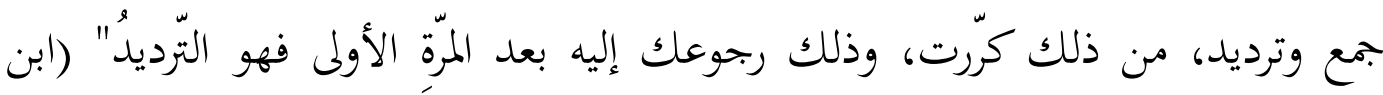

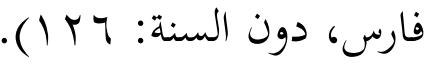
واختلف العلماء من اللغويين والمفسرين في تعريف التكرار اصطلاحا. عرّه ابن

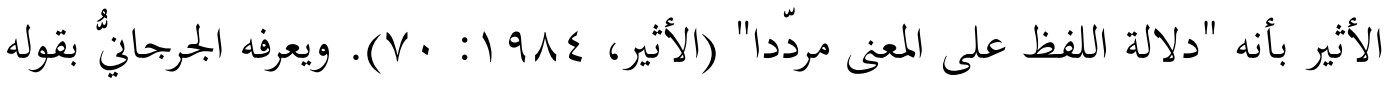

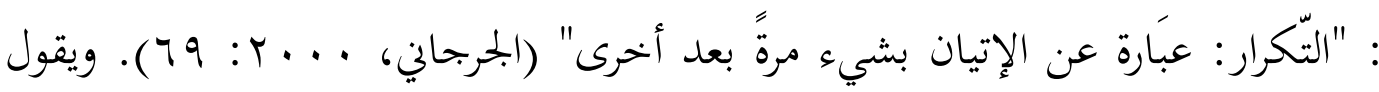

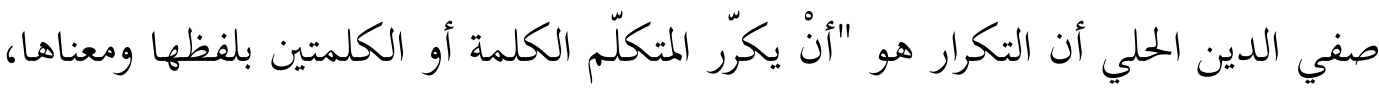

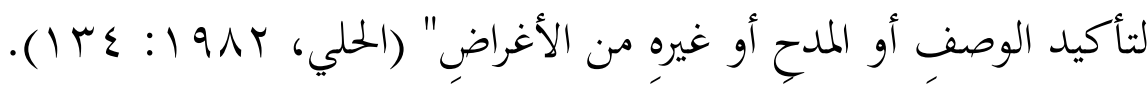

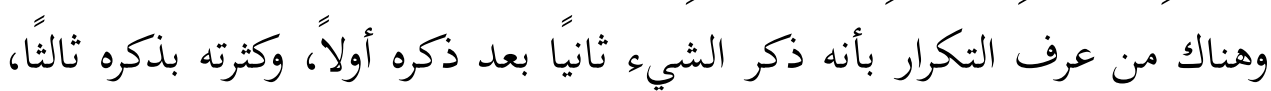

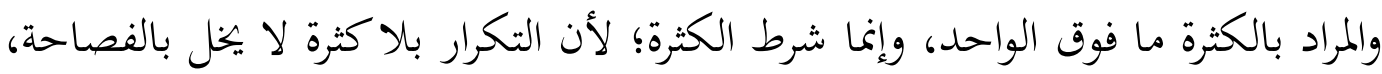

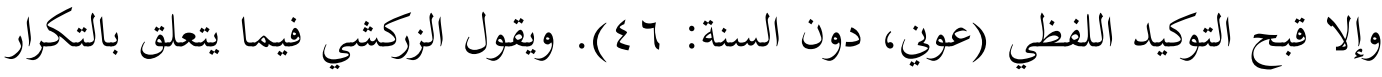

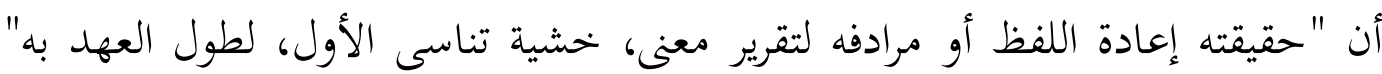

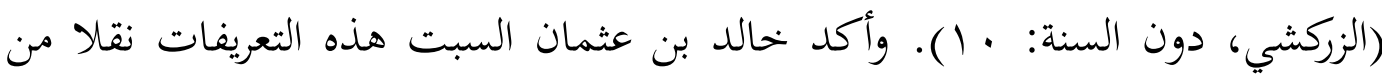

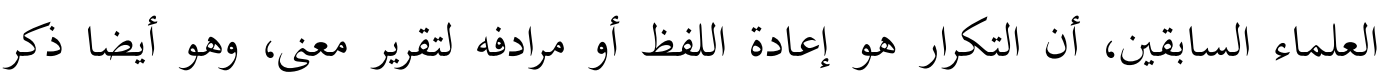

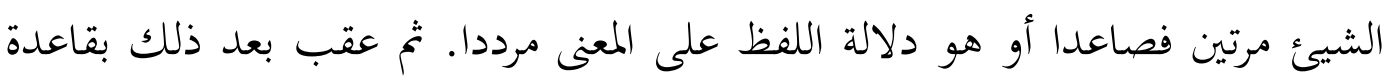

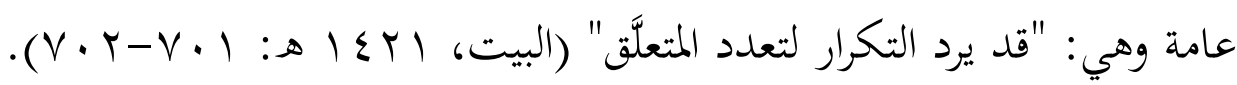

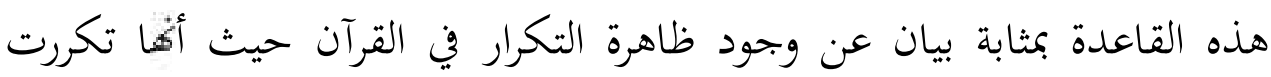
بعض الآيات أو الجمل، في بعض سور القرآن في مواضع خختلفة. وهذه الظاهرة مما أثار

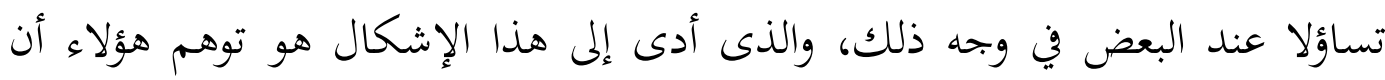

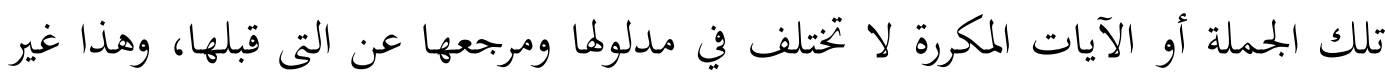

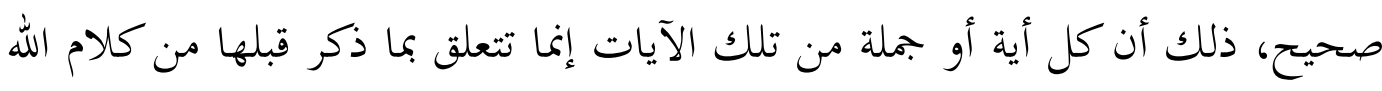

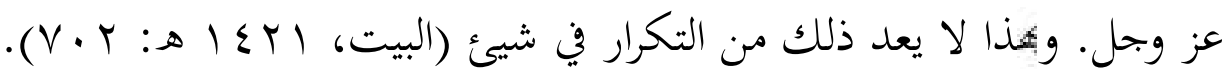

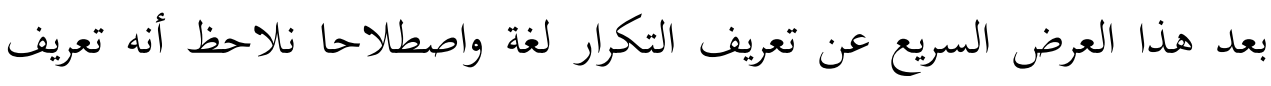

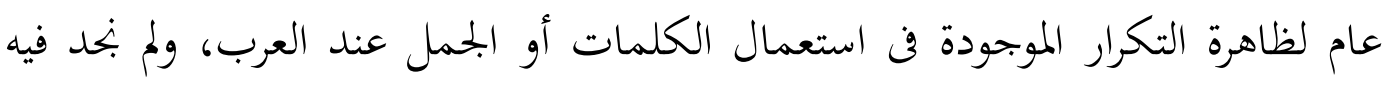

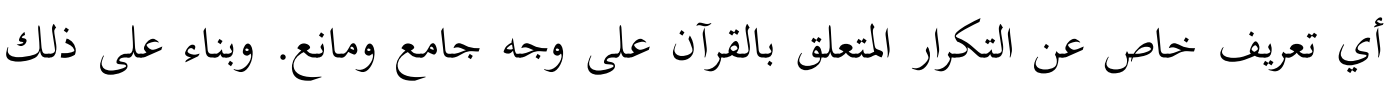


سعى الباحث إلى تقليم وتشكيل تعريف جديد مع مراعاة النظر إلى جميع ظواهر التكرار

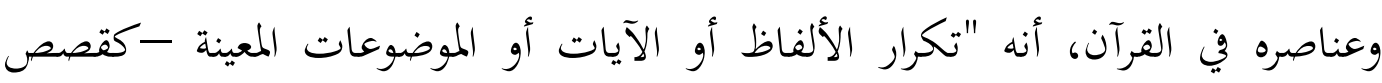
الأنبياء والأمم الغابرة أو الخبر عن الجنة والنار وكذلك الترغيب والتهرات الترهيب ونهوها-

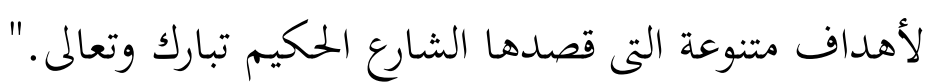

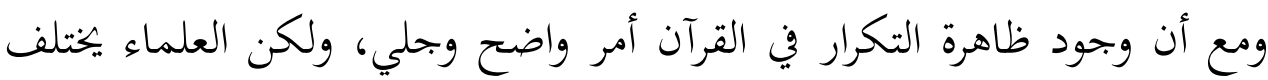

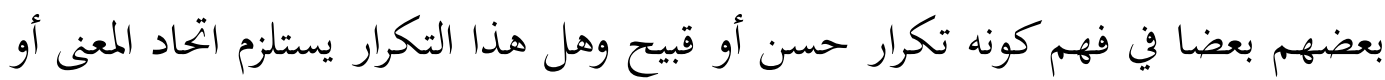
أنه يدل على تنوع المعانى باختلاف المواضع؟ هذه الأسئلة وما يجرى حولها سنعرضها ونشرحها في السطور الآتية بإذن الله.

\section{التكرار في القرآن}

من خلال عرض بعض التعريفات السابقة يظهر لي أن مصطلح التكرار مصطلح

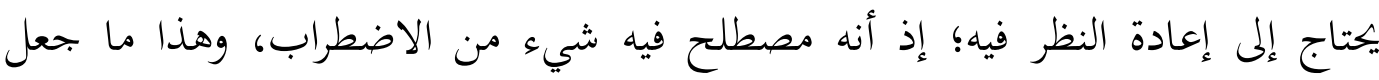

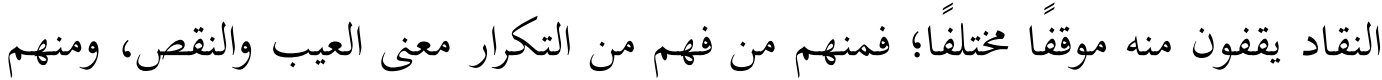

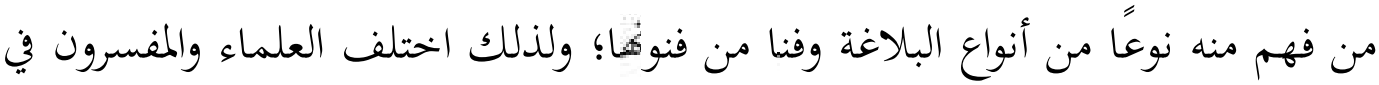

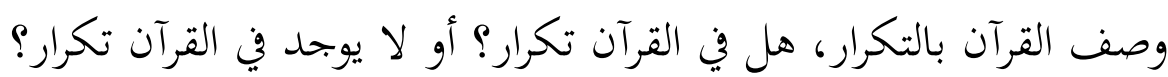

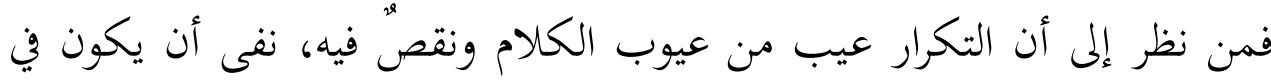
القرآن تكرار، فوقع في إشكالية المصطلح، فماذا يمكن أن يطلق على التعدد في قوله

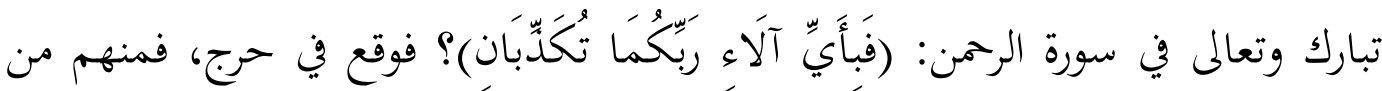

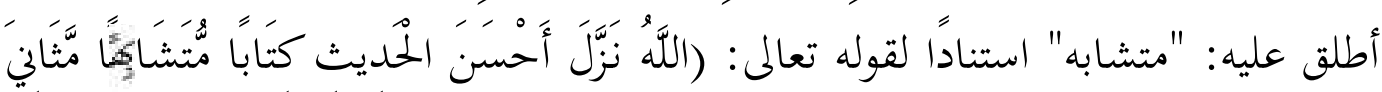

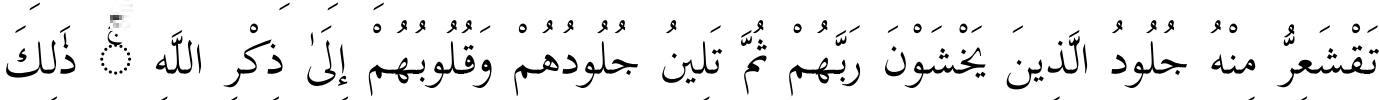

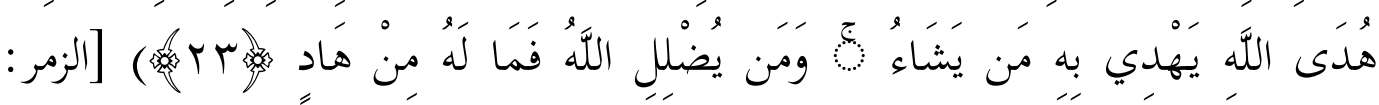
. [tr وعلى هؤلاء نورد تساؤلاً: التشابه يقتضي الاختلاف، فمن أطلق على الآيات التي وردت في سورة الرحمن -على سبيل المثال- متشابهات، فما الاختلاف الذي بينها؟! فأي تشابه لابد أن يقتضي بعض الجوانب التي يكون فيها اختلاف، فما هي 
وهذه الطائفة من العلماء الذين نفوا وجود التكرار في القرآن يميلون إلى تضييق معنى التكرار وحصره في إعادة اللفظ نفسه في سياق واحد، فإذا لم يكن المعاد اللفظ نفسه، أو أعيد اللفظ أكثر من مرة ولكن لكل موضع سكرة سياقه الخاص ومعناه الخاص، فلا يكون ذلك تكرارا، وعليه يكون التكرار في الكلام معيبا غير مقبول، ولا يدخل فيه

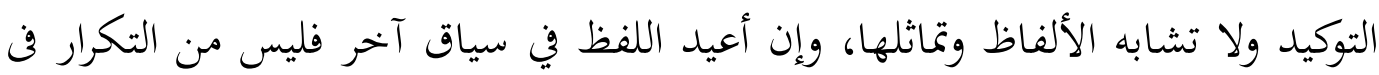
شيئ.

وقد اختار بهذا الرأي ومال إليه عدد من العلماء، منهم أبو جعفر محمد ابن جرير الطبري، الذى ينفى التكرار في الآيات المتقاربة أو المتتابعة بقوله: "وغير موجود في شيئ من كتاب الله آيتان متجاورتان مكررتان بلفظ واحد ومعنى واحد، لا فصل بينهما

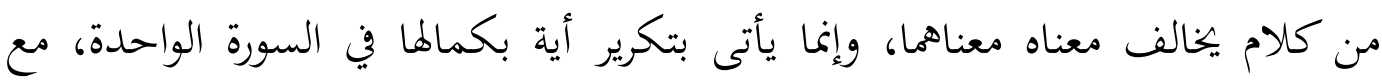
فصول تفصل بين ذلك، وكلام يعترض به بغير معنى الآيات المكررات، أو غير ألفاظها" (الطبري، 971 1: ـ ד).

ثم أكّد سيد قطب نفي التكرار في القرآن بقوله: "ويحسب أناس أن هنالك تكرارا

في القصص القرآني، لأن القصة الواحدة قد يتكرر عرضها في صور شتى، ولكن النظرة

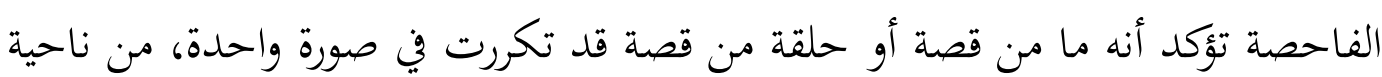
الغرض الذي تساق القصة من أجله، وطريق الأداء في السياق، وأنه حيثما تكررت

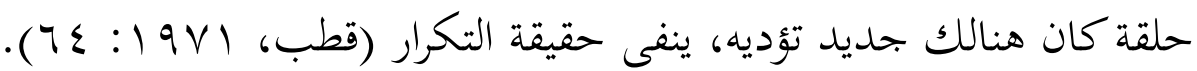
ووافق على رأي سيد قطب شقيقه محمد قطب في ظاهرة التكرار حيث قال: "إن

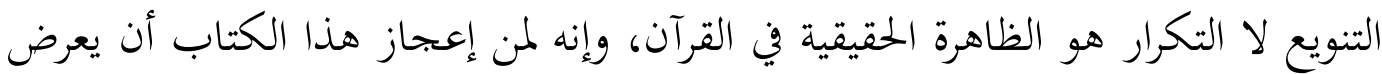
الموضوعات التى يكرر ذكرها للتذكير والتربية والتوجيه، بهذا القدر المعجز من التنويع بحيث لا تتكرر صورتان متماثلتان أبدا في القرآن كله، على كثرة المواضع التى يرد فيها

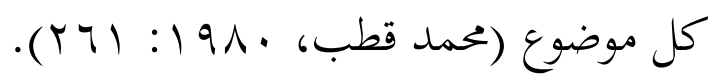

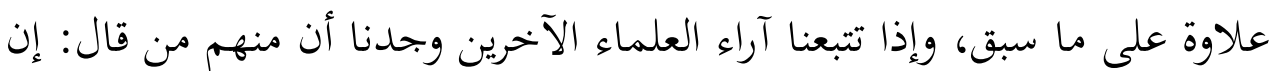

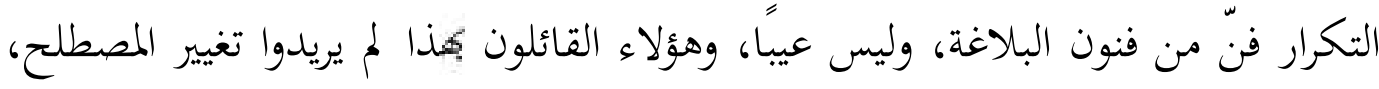


فنفوا الإشكالية التي تَرّ عليهم، وقسّموا التكرار إلى قسمين: قسم حسن، وقسم قبيح، التها وجعلوا التكرار الذي في القرآن من القسم الحسن.

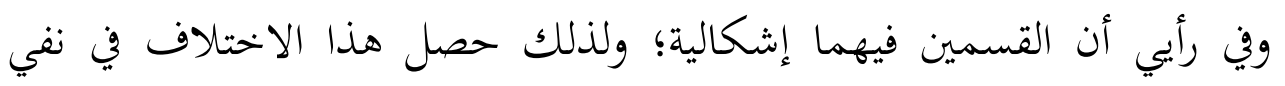
الظاهرة وإثباتها في القرآن، فلو أطلقنا على هذه الظاهرة التعدد لخرجنا من إشكالية

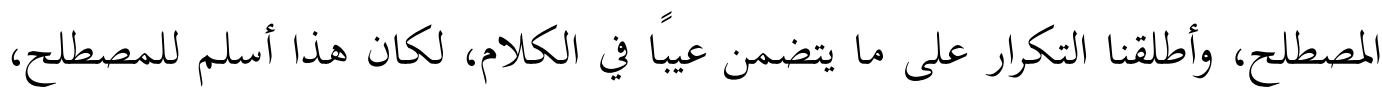
وأدق له، وأبعد عنهم الخلاف في التسمية. وها هنا نلاحظ أن هناك أمر آخر في غاية الأهمية أيضا، وذلك أن في في التكرار

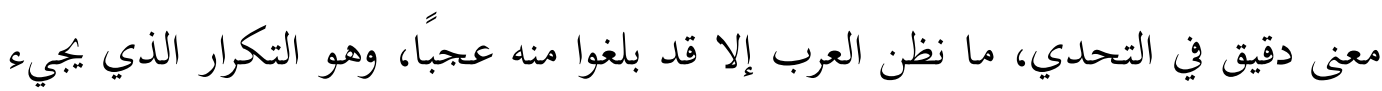

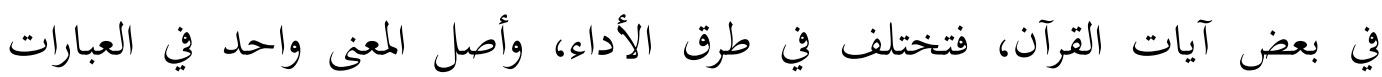

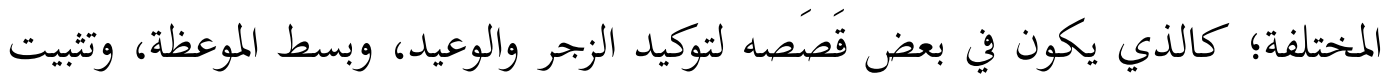

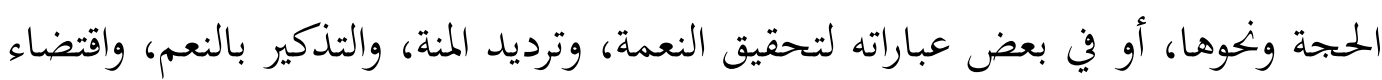

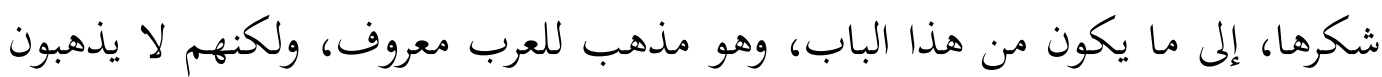
إليه إلا في ضروب من خطابهم؛ للتهويل والتوكيد والتخويف والتفجع، وما بيجري بحراها

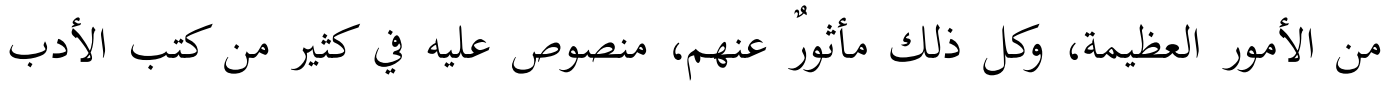

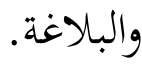

بيدَ أن وروده في القرآن مما حقق للعرب عجزهم بالفطرة عن معارضته، وأثهم

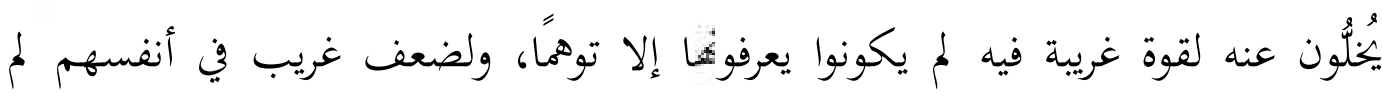

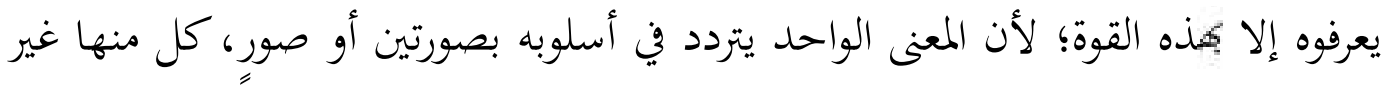

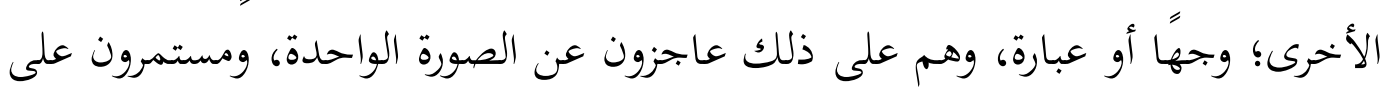
العجز لا يطيقون ولا ينطقون.

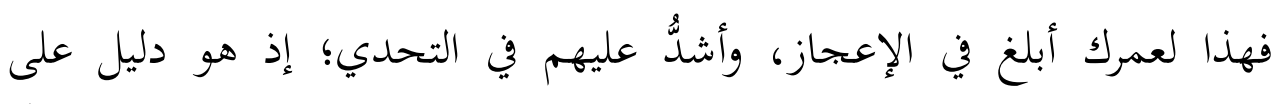
بحاوزفم مقدارَ العجز النفسي الذي قد تمكن معه الاستطاعة أو تتهيأ المعاريض حينًا

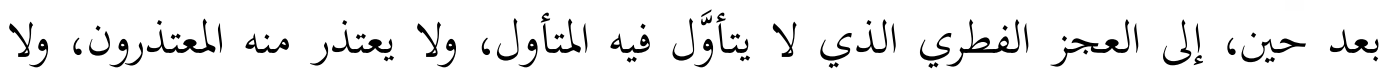
يجيري الأمر فيه على المسامحة. إلى العزي. 
وفي هذا الإطار يقول مصطفى صادق الرافعي عن أهمية التكرار: "وقد خفي هذا المعنى -التكرار- على بعض الملحدة وأشباههم، ومن لا نَفَاذ لهم في أسرار العربية ومقاصد الخطاب، والتأي بالسياسة البيانية إلى هذه المقاصد، فزعموا به المزاعم

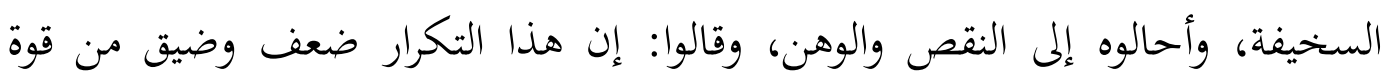

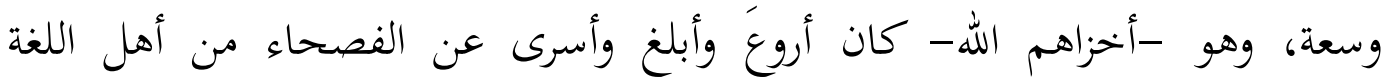

$$
\begin{aligned}
& \text { والمتصرفين فيها (الرافعي، • 199 1: ع 19 ). } \\
& \text { أنواع التكرار في القرآن }
\end{aligned}
$$

قسَّم العلماء التكرار الوارد في القرآن إلى نوعين :

$$
\text { أحدهما : تكرار اللفظ والمعنى }
$$

وهو ما تكرر فيه اللفظ دون اختلاف في المعنى، وقد جاء على وجهين:

$$
\text { موصول، ومفصول. }
$$

• أما الموصول: فقد جاء على وجوه متعددة: إما تكرار كلمات في سياق

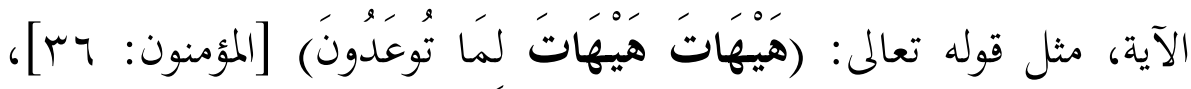

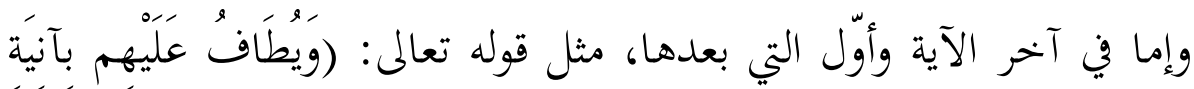

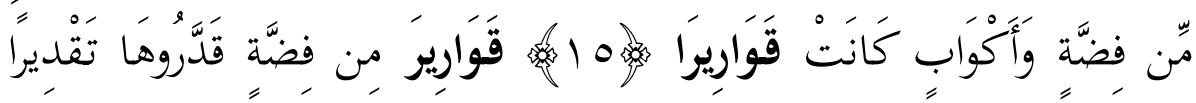

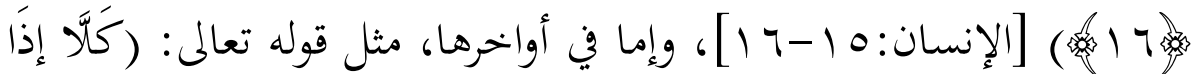

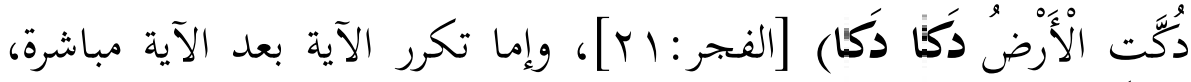

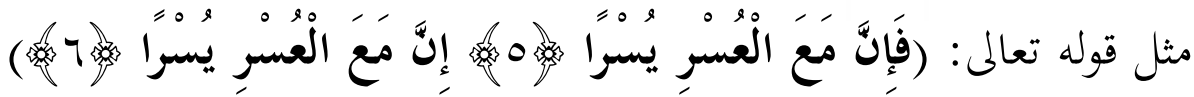

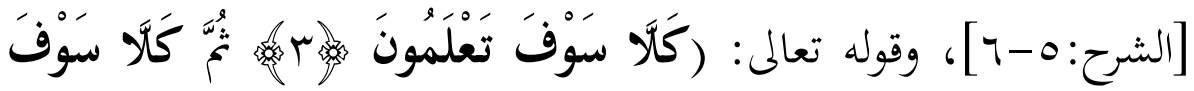
تَعْلَمَونَ

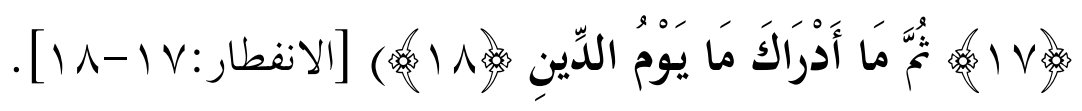
• وأما المفصول: فيأتي على صورتين: إما تكرار في السورة نفسها، وإما تكرار

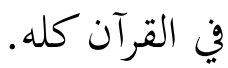
مثال التكرار في السورة نفسها: 


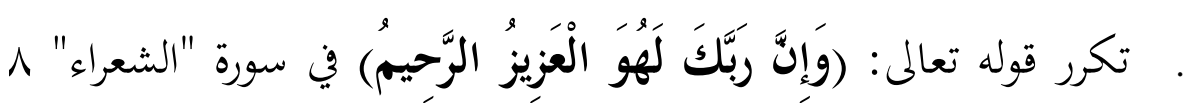

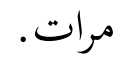

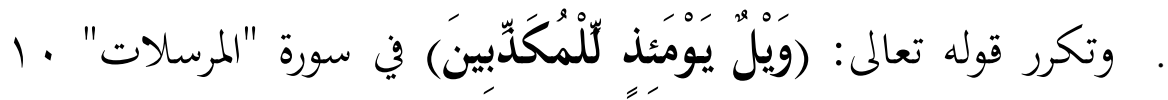

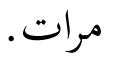

. في سورة "القمر" مظهر من مظاهر التكرار، هو قوله تعالى: (وَلَقَدْ

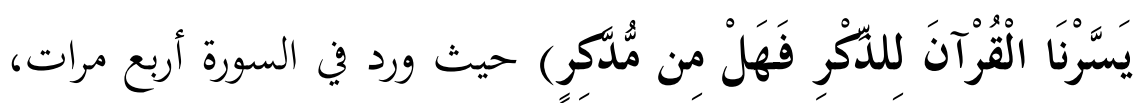

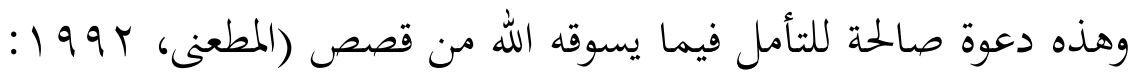
$\cdot($ r

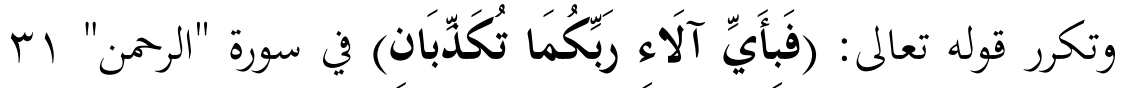
مرة؛ ثمانية منها ذكرت عقيب آيات فيها تعداد عجائب خلق الله، وبدائع صنعه (وهي الآيات من 17 إلى عَ)، ومبدئ الخلق ومعادهم.

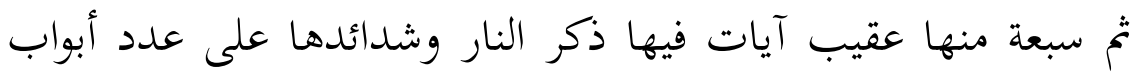
جهنم (والسبعة الثانية من عץ إلى 0؟). وحسن ذكر الآلاء عقيبها،

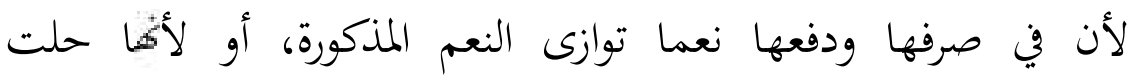

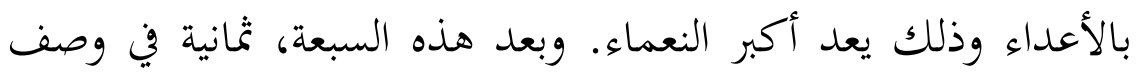

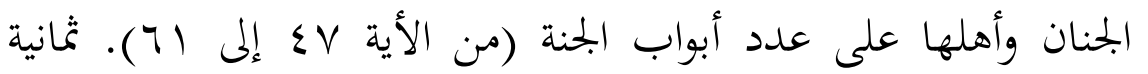

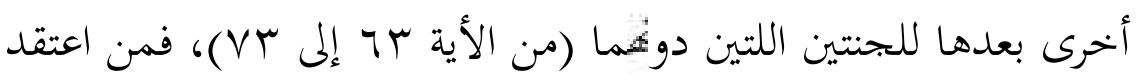
الثمانية الأولى وعمل بموجبها استحق كلتا الثمانيتين من الله، ووقاه

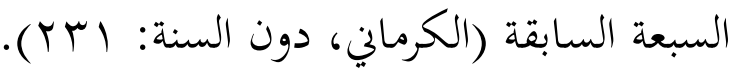

$$
\begin{aligned}
& \text { ومثال التكرار في القرآن كله: }
\end{aligned}
$$

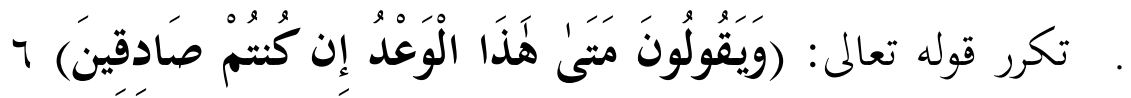

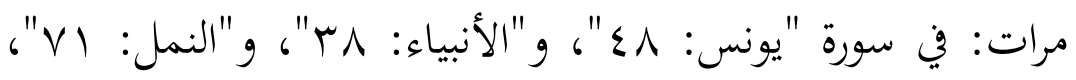

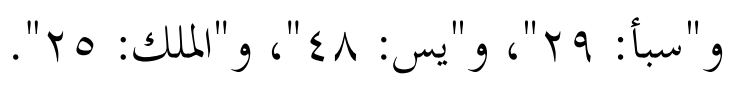




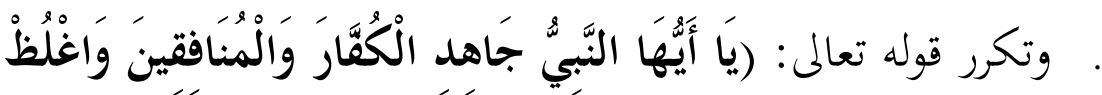

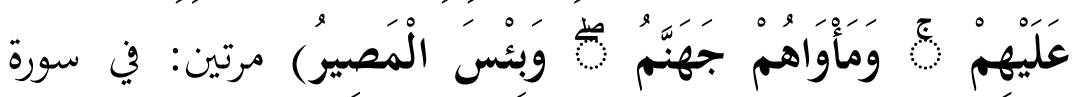

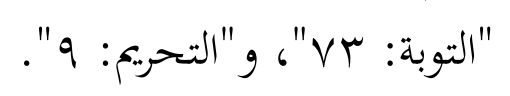

والثاني : النكرار في المعنى دون اللفظ.

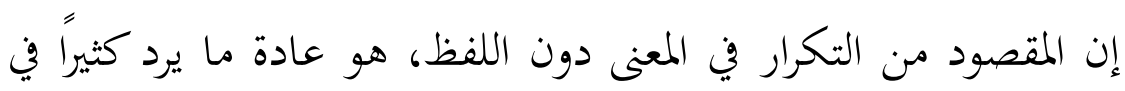

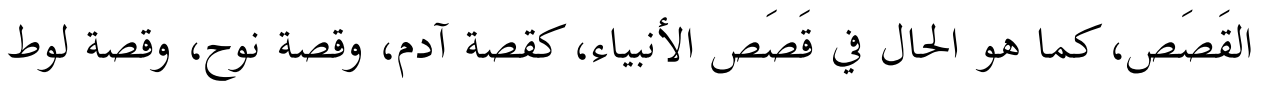

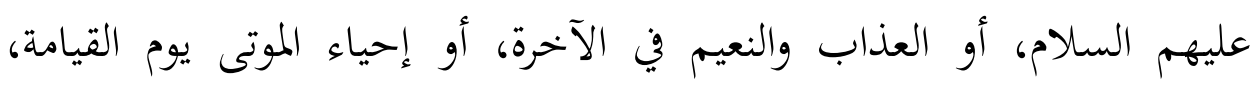

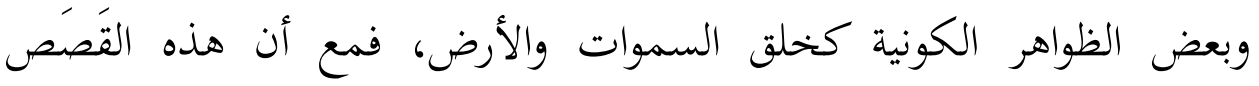

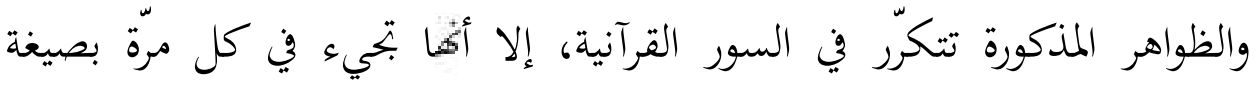

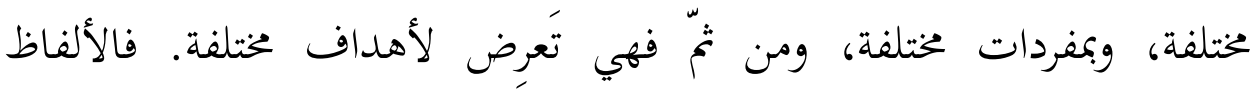

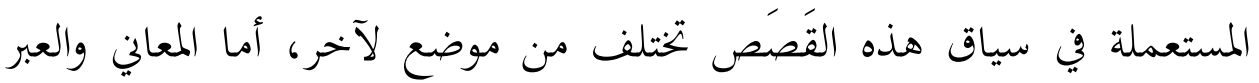

$$
\text { فتتكرّ من حين لآخر. }
$$

ومن أمثلة هذا النوع من التكرار، قصّة آدم عليه السلام المكررة في

$$
\text { سورتى البقرة والأعراف: }
$$

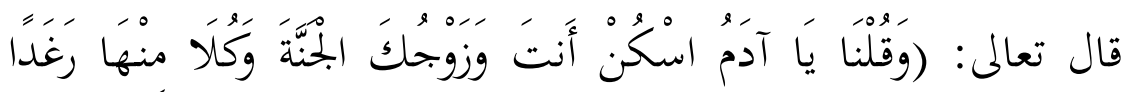

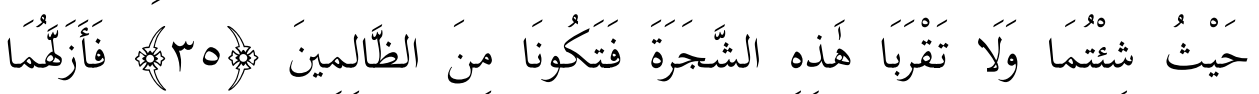

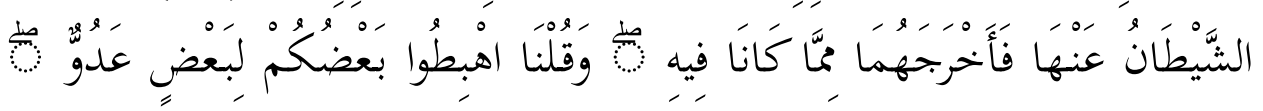

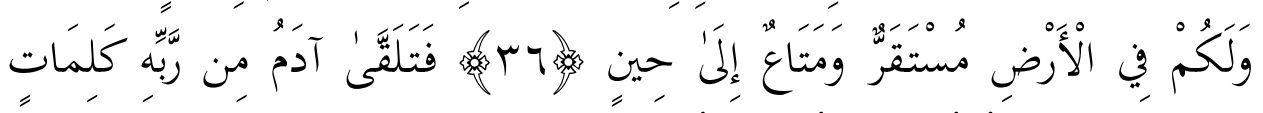

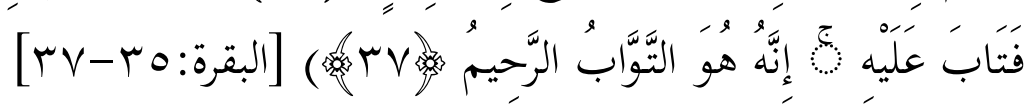

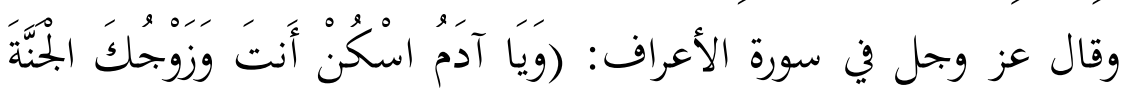

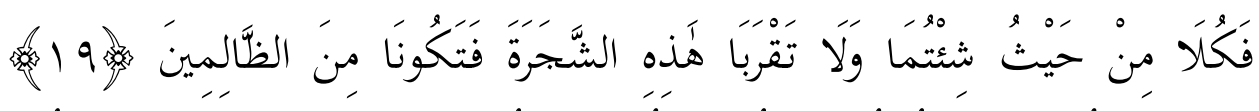

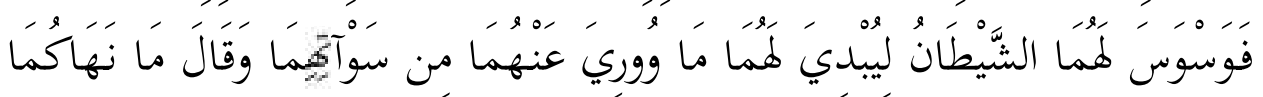

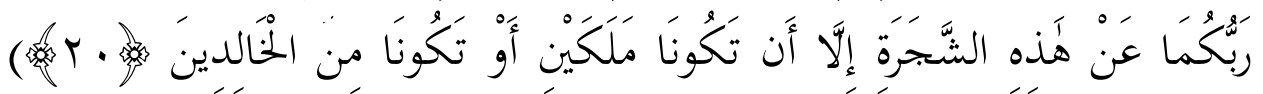

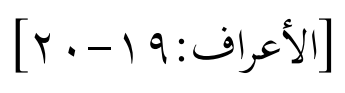


بعد قراءة تلك الآيات من سورتى البقرة والأعراف، وجدنا أثها تتحدث عن قصة آدم عليه السلام عندما كان في الجنة وثهي الله له عن التقرب إلى له

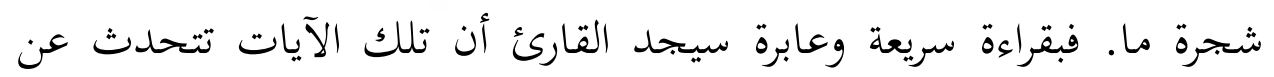

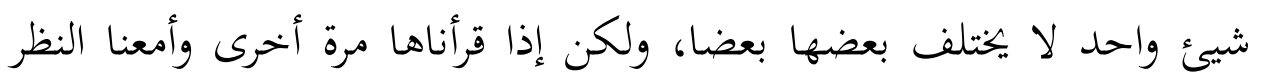
فيها سنجد أن بينها علاقة مشتركة حتى تتكامل القصة بتفاصيلها وتتزايد حكمها. وهناك مثال آخر يتعلق بالتكرار المعنوي في القرآن، وذلك على النحو

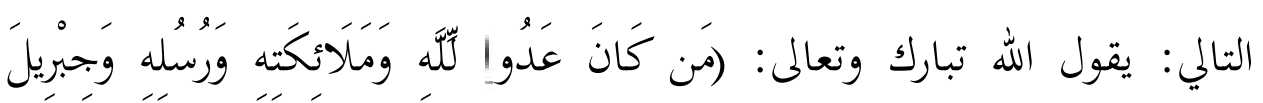

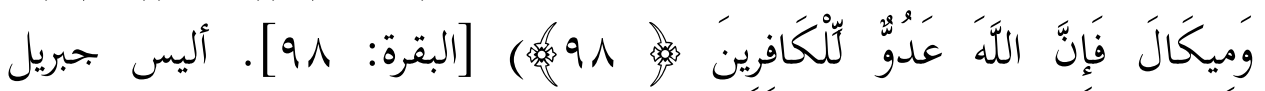

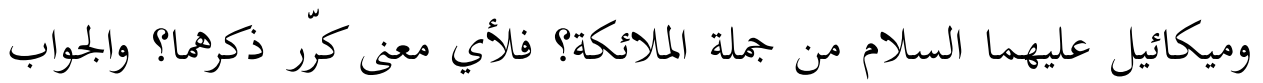
على هذا: إن العرب طريقة في الحذف والتكرار، فالحذف للإيجاز والتقصير، والتكرار للتقسيم والتفصيل. وقد قيل: إن في التكرار ربما يكون زيادة فائدة

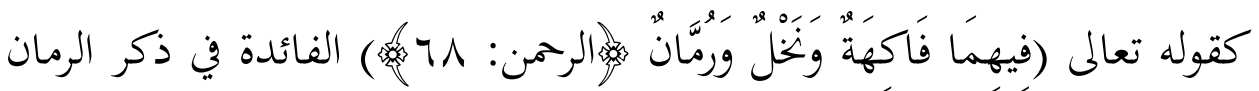
والنخل وعطفه على الفاكهة: تشريف لمما على الفواكه. وهذه الأية من جملتها، عطف جبريل وميكائيل عليهما السلام على الملائكة تشريفا لمما (السمرقندي، .$(190: 1911$

وإضافة إلى التقسيم السابق لأنواع التكرار في القرآن، هناك نوع آخر من التكرار

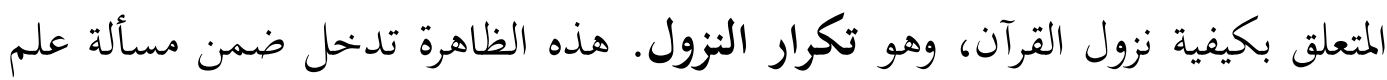

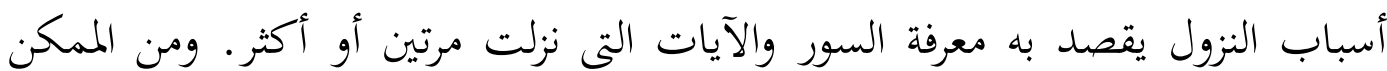

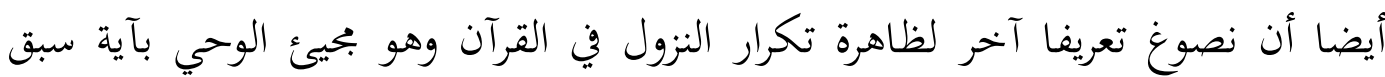

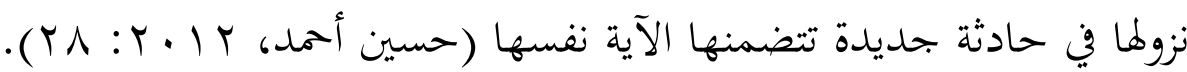
هناك أسباب عديدة ألجأت بعض العلماء والباحثين إلى القول بتكرار النزول، أشار إليه عبد الرزاق حسين أحمد في مقالته، نلخصها فيما يلى: 
تعدد روايات أسباب النزول وتعارضها، فصار القول بذلك ملجأ يلجأ إليه

عند عدم التوفيق بين تلك الأقوال.

الاختلاف في مكية سورة أو مدنيتها، أو أن يقال: إن الآية نزلت في المدينة في حين أن السورة التى اشتملت عليها مكية، وقد يكون العكس.

$$
\text { . الاختلاف في أوجه القراءات. }
$$

· الوهم الواقع من قبل بعض الرواة حيث يقول: "فنزل" بدل "فتلا" مما يجعل

البعض يتصور عند حصول التعارض عندئذ أن النزول قد تكرر.

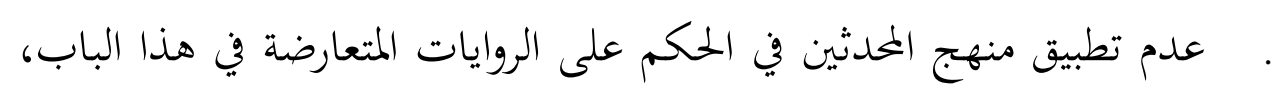

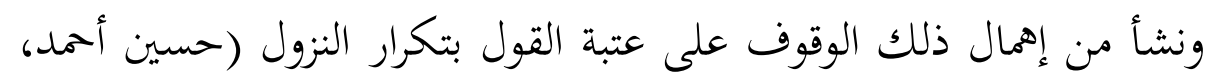

$$
\cdot(r+r-r \cdot t \cdot 1 r
$$

هذه هي بعض أنواع التكرار التى يمكن عرضها في هذا البحث، ولا مانع أن يكون هناك نوع آخر من التكرار يتلمسه من يقرأ القرآن ويتدبره.

\section{فوائد التكرار في القرآن}

ولقد علمنا ممّا سبق أن العلماء اختلفوا في دلالة توظيف هذه الظاهرة البارزة في النصّ القرآني، ورأينا أهم انقسموا إلى فريقين: فريق نافٍ للتكرار تمامًا، وفريق مؤيّد له.

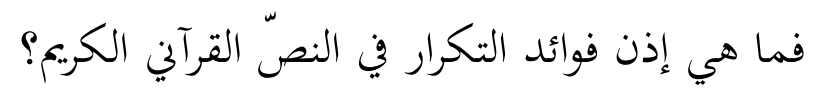
يقول ابن تيمية رحمه الله: "وليس في القرآن تكرار محض، بل لإبـ لابد من فوائد في

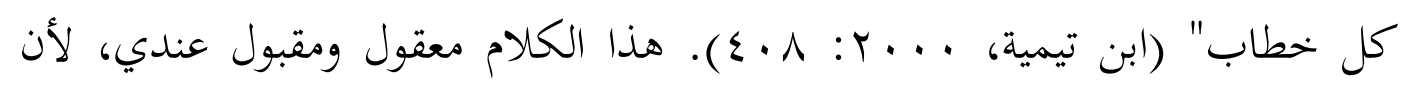

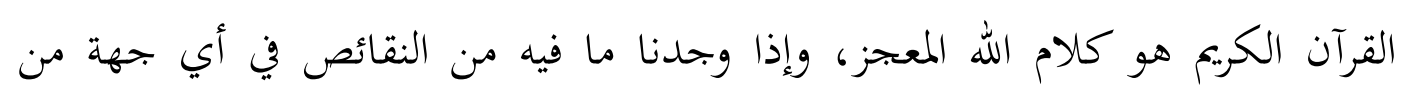

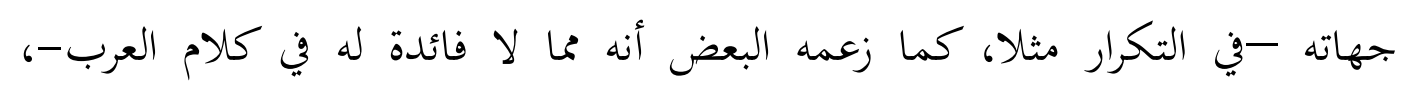
فسيكون القرآن ضعيفا.

وقال ابن تيمية - رحمه الله - في التعليق على تكرار قصة موسى مع قومه: "وقد ذكر الله هذه القصة في عدة مواضع من القرآن، يبين في كل موضع منها من الاعتبار

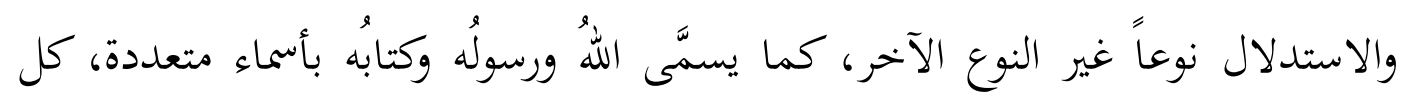

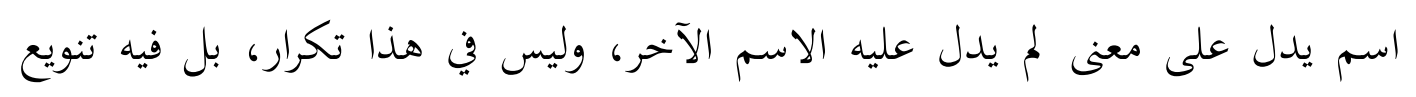


الآيات مثل أسماء النبي صلى الله عليه وسلم إذا قيل: محمد، وأحمد، والحاشر، والعاقب، والمقفى، وبي الرمة، وببي التوبة، وببي الملحمة، في كل اسم دلالة على معنى ليس في الاسم الآخر، وإن كانت الذات واحلدة فربه فالصفات متنوعة.

وكذلك القرآن إذا قيل فيه: قرآن، وفرقان، وبيان، وهدى، وبصائر، وشفاء، ونور، ورمة، وروح: فكل اسم يدل على معنى ليس هو المعنى الآخر. وكذلك أسماء

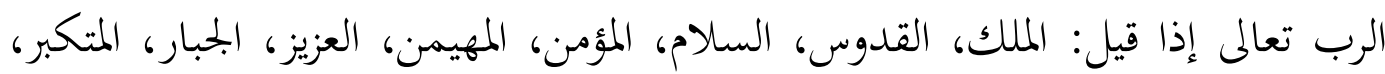

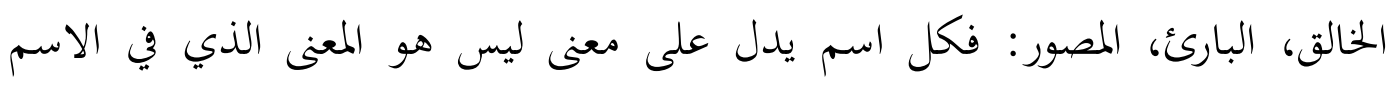

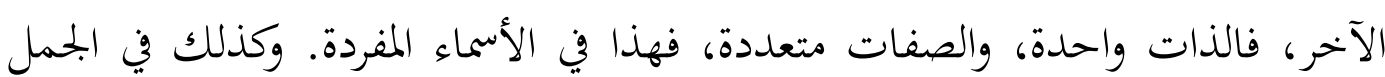

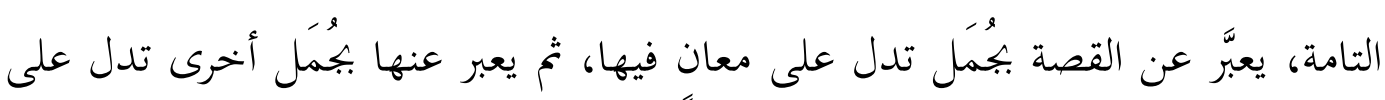

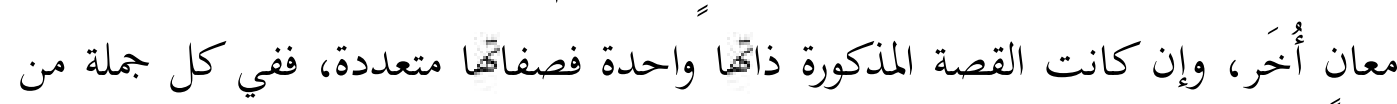

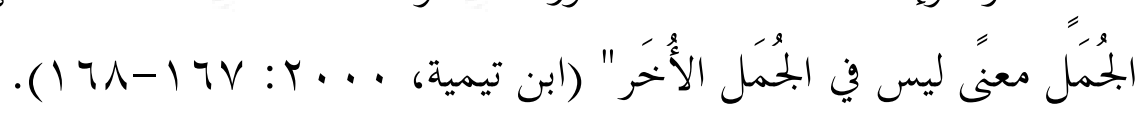

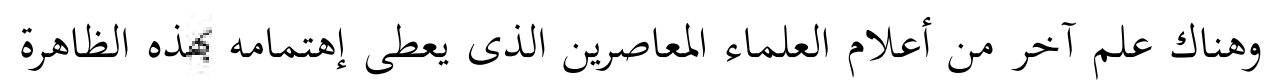
وهو بديع الزمان سعيد النورسي إذ يقول: "إن قلت: إن في القرآن الموجز المعجز أشياء مكررة تكرارا كثيرة في الظاهر كالبسملة و (فبأي آلاء) إلخا... و و(ويل يومئذ) إلخ... وقصة موسى وأمثالها، مع أن التكرار يمل ويناف البلاغة.

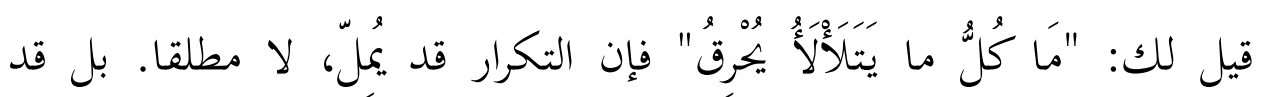

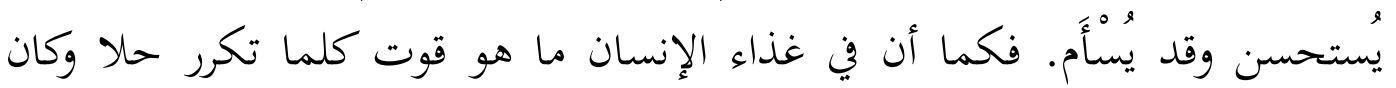

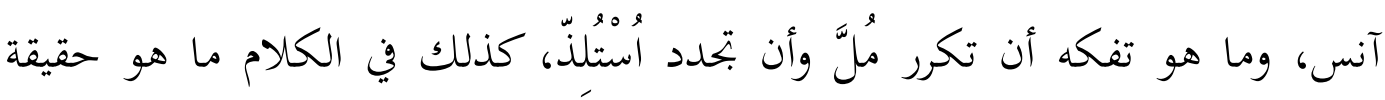
وقوت وقوة للأفكار وغذاء للأرواح كلما استعيد استحسن واستئنس بمألوفه كضياء الشمس. وفيه ما هم من قبيل الزينة والتفكه، لذته في تجدد صورته وتلون لباسه"

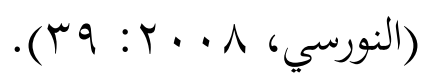

وقال السيوطي - رحمه الله -: وله - أي : التكرار - فوائد، منها (السيوطي،

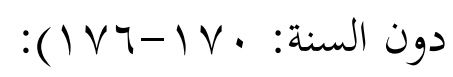

) للتقرير، وقد قيل "الكلام إذا تكرَّر تقرَّر"، وقد نبه تعالى على السبب الذي

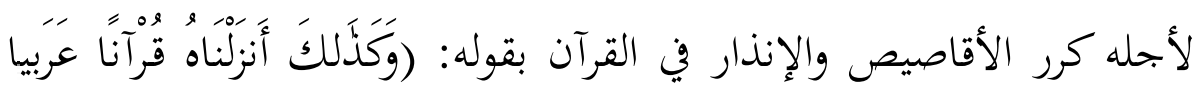




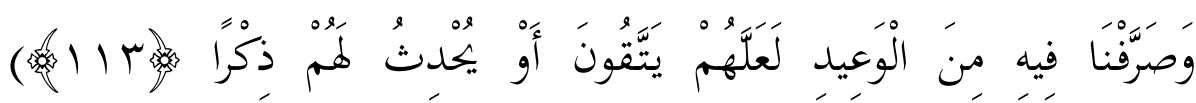

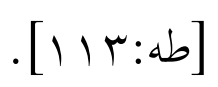

) للتأكيد. قال الإمام السيوطي: التكرير هو أبلغ من التأكيد، وهو من

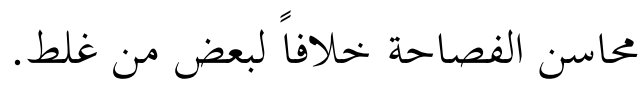

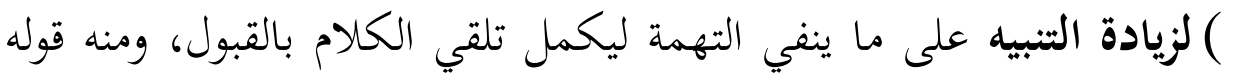

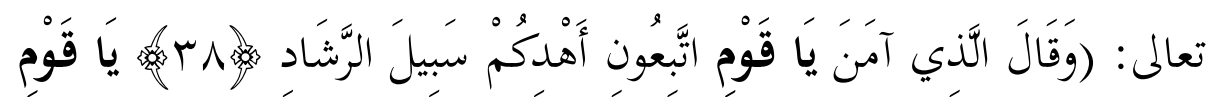

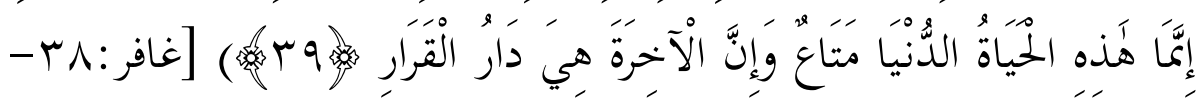

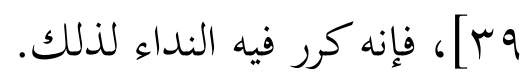

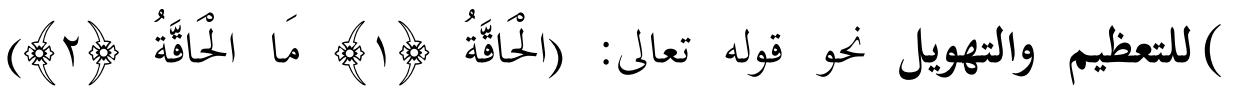

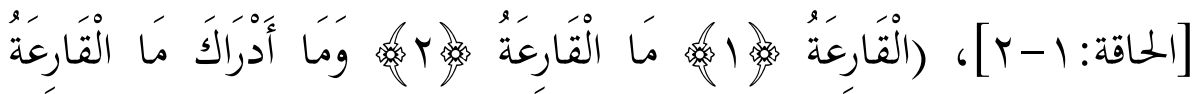

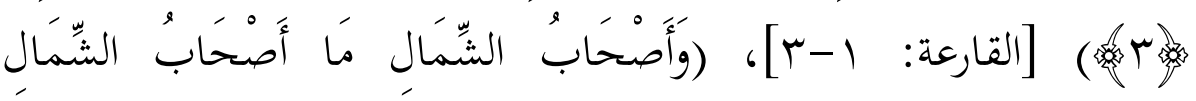
.

وإضافة إلى ما سبق شرحه، فهناك فوائد وحكم أخرى للتكرار كما عرضه الخها العلماء نوردها على وجه بحمل فيما يلى:

. التيسير على قارئ القرآن. يقول الأستاذ بديع الزمان سعيد النورسي بيانا

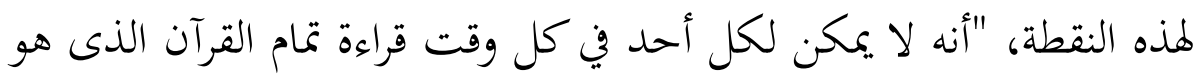

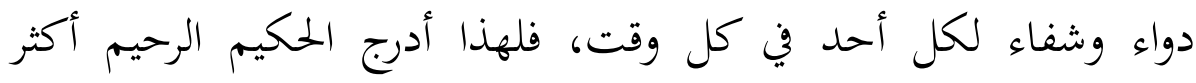

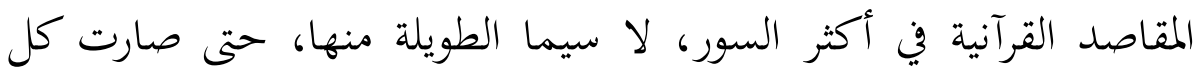

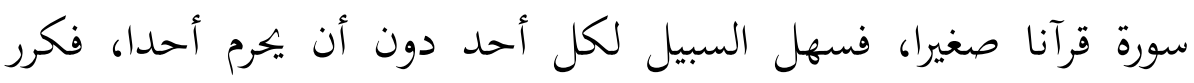

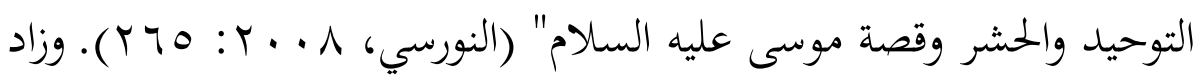
على البيان في موضع آخر بقوله: "لأن كثيرين لا يستطيعون قراءة كل

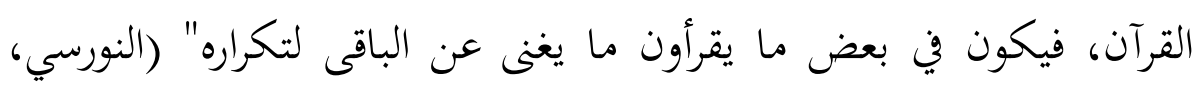

$$
\text { (r) }
$$

وقد أشار إلى هذه الحكمة أيضا ابن قتيبة إذ يقول: "كانت وفود

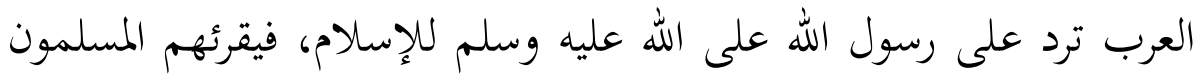


شيئا من القرآن، فيكون ذلك كافيا لهم، وكان يبعث إلى القبائل المتفرقة بالسور المختلفة، فلو لم تكن الأنباء والقصص مثناة ومكررة لوقعت قصة موسى إلى قوم، وقصة عيسى إلى قوم، وقصة نوح إلى قوم، وقصة لوط إلى

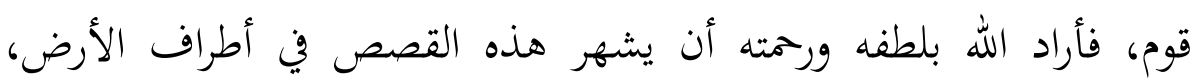

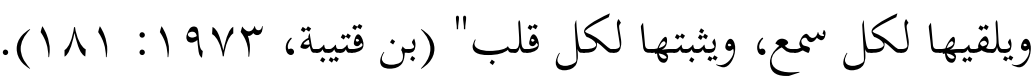

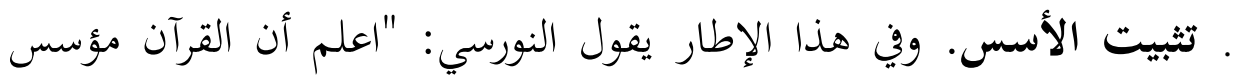

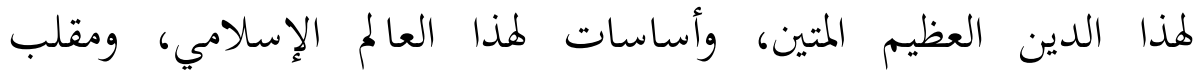
لاجتماعيات البشر ومحولها ومبدها، وجواب لمكررات أسئلة الطبقات

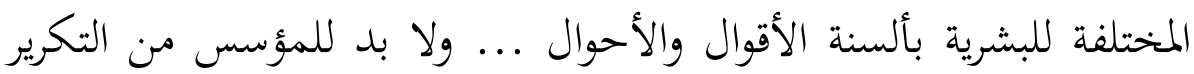

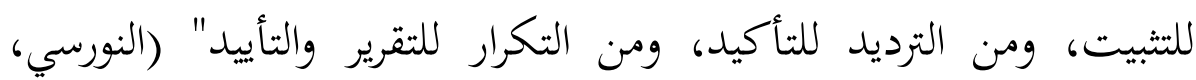
$\cdot(r \top \Lambda: T \cdot N$

ومن الممكن جعل هذه النقطة فرعا من النقطة التى بينها السيوطي سابقا، أن تثبيت الأسس يندرج ضمن التقرير والتأكيد، إلا أن النورسي رغب في إفراده بنقطة خاصة للتأكيد على أهمية الأسس الاعتناء بها وحاجتها إلى تكرر لتثبت في النفوس، وبين في هذه النقطة أن القرآن الكريم

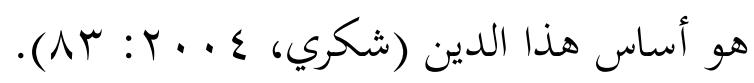
تنوع الأساليب. وأشار النورسي إلى هذه الحكمة بقوله: "اعلم أن القرآن

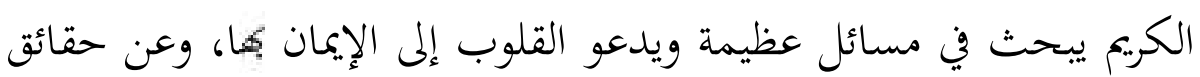
دقيقة ويدعو العقول إلى معرفتها، فلا بد لتقريرها في القلوب وتثبيتها في أفكار العامة من التكرار في صور مختلفة وأساليب متنوعة" (النورسي، $\cdot(V): r \cdot \lambda$

وقد ذكر العلماء من فوائد التكرار أمورا كثيرة يمكن أن تندرج ضمن هذه النقطة، مثل: التعظيم والتهويل، الوعيد والتهديد، والتنويه والإشادة،

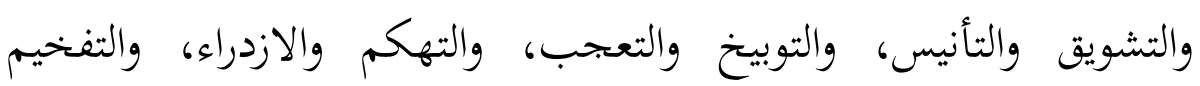

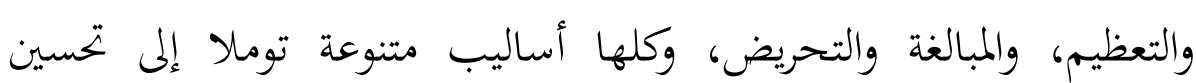


الكلام، كما يتميز أسلوب القرآن بالتنوع في العرض، ويمكن أن يمثل لهذا بالقصص القرآني، والآيات التى تتحدث عن اليوم الآخر وإثباته، وهي من

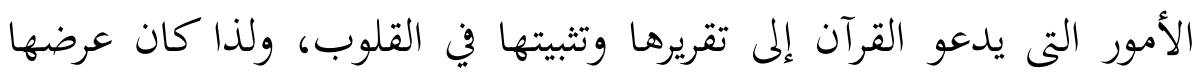
بأساليب متعددة وصور متنوعة، ليكون لهذا التنويع أثره العظيم في النفوس.

الخلاصة

وفي ختام هذا البحث المتواضع نخلص إلى أن التكرار أسلوب أدبي رصين سلكه

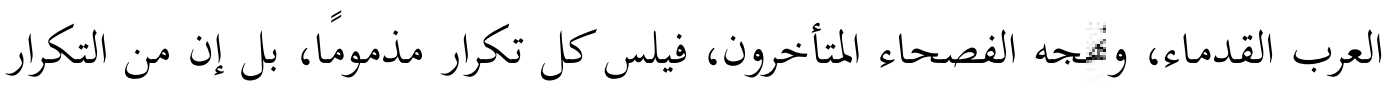
ما يزيد الكلام حلاوة وطلاوة، ومن خلال البحث تبين أن هناك من نفى التكرار في

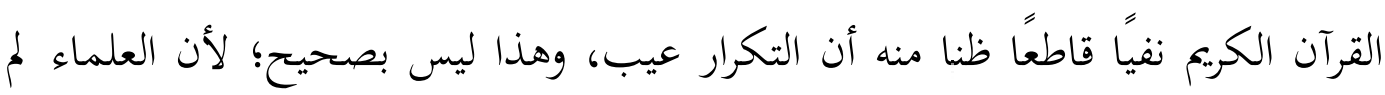

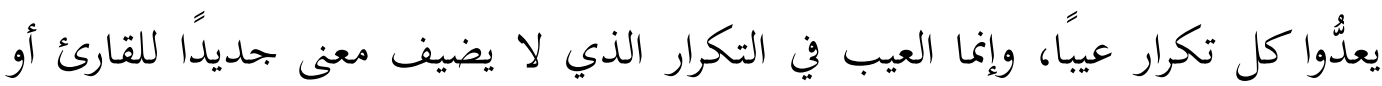

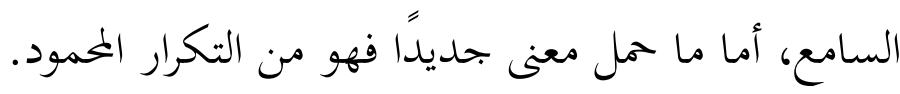
المراجــع ابن الأثير، ضياء الدين. المثل السائر في أدب الكاتب والشاعر. تحقيق أحمد الحوفي

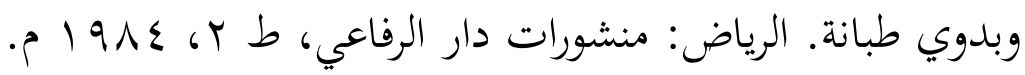

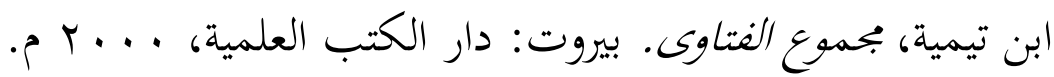
ابن فارس. معجمم مقاييس اللغة. تحقيق عبد السلام محمد هارون. بيروت: دار الفكر، دون السنة.

ابن قتيبة، أبو محمد عبد الله بن مسلم. تأويل مشكل القرآن. مقدمة المحقق، تحقيق:

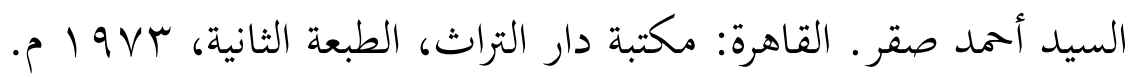
ابن منظور. لسان العرب المحيط. إعداد وتصنيف يوسف خياط. بيروت: دار لسان

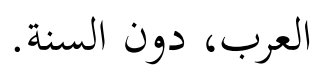
أحمد، عبد الرزاق حسين. مسألة تكرار النزول في القرآن الكحيم بين الإثبات والنغي. منشور في بحلة الوعي الإسلامي بحلة كويتية شهرية جامعة، الإصدار الثالث

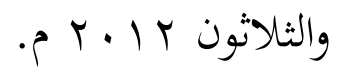
البيت، خالد بن عثمان. قواعد التفسير جمعا ودراسة. دار ابن عفان، اب إ ا هـ. 
الجرجاني، الشريف. التعريغات . بيروت: دار الكتب العلمية ، ط. ا، . . . Y م.

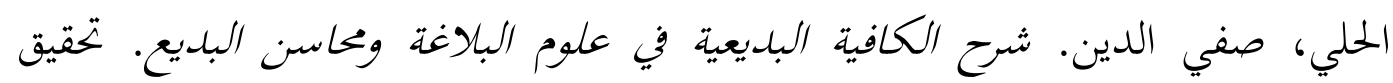

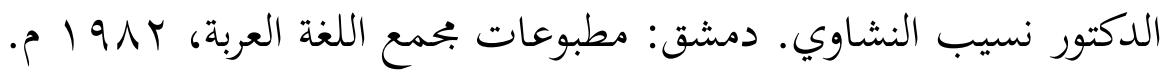
الرافعي، مصطفى صادق. إعجاز القرآن والبلاغة النبوية. بيروت: دار الكتاب العربي، .8199 .

الزركشي، بدر الدين محمد بن عبد الله. البرهان في علوم القرآن. تحقيق محمد أبو الفضل

$$
\text { إبراهيم. لبنان: دار المعرفة، دون السنة. }
$$

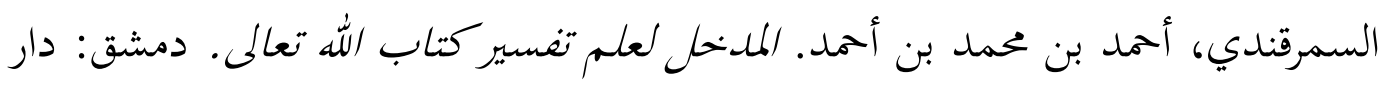

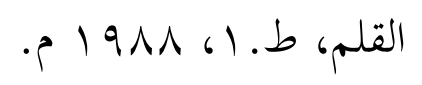

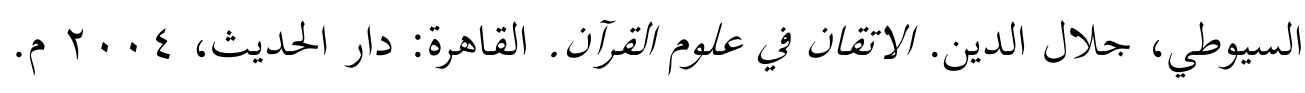
شكري، أحمد خالد. بكوث في الإعجاز والتنسير في رسائل النور. القاهرة: سوزلر

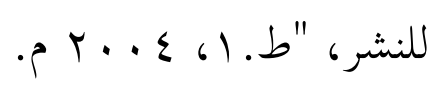

الطبري، محمد ابن جرير. جامع البيان عن تأويل آي القرآن. القاهرة: مصطفى الباب

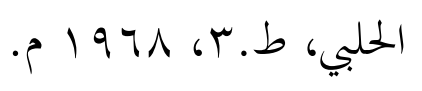

عوني، حامد. الواضح للبلاغة. القاهرة: المكتبة الأزهرية للتراث، دون السنة. الفقي، صبحي إبراهيم. علم اللغة النصي بين النظرية والتطبيق. القاهرة: دار قباء

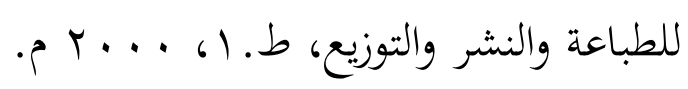

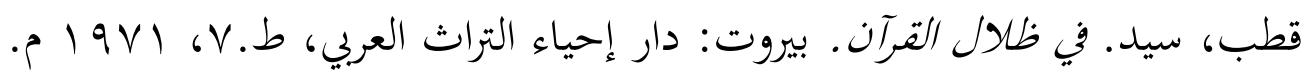

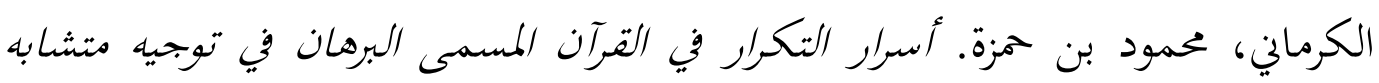
القرآن لما فيه من الحجة والبيان. دار الفضيلة، دون السنة.

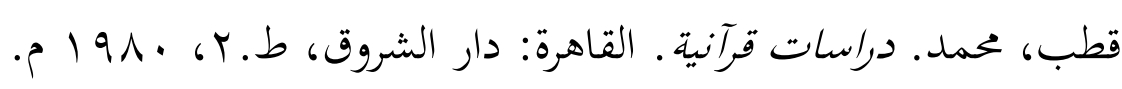
المطعنى، عبد العظيم إبراهيم محمد. خصائص التعبير القرآني ولماته البلاغية. القاهرة:

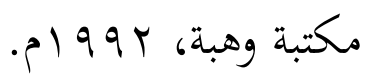
النورسي، بديع الزمان سعيد. إثارة الإعجاز في مظان الإيباز. القاهرة: سوزلر للنشر،

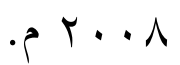


. الشعاعات. القاهرة: سوزلر للنشر، م . . ب م.

. الكلمات. القاهرة: سوزلر للنشر، م . . ب م.

• المثنوي العربي النوري. القاهرة: سوزلر للنشر، م . . ب م.

. المكتوبات. القاهرة: سوزلر للنشر، م م. . ب م. 